\title{
Determinants of Poor Utilization and Accessibility of Immunization Services: A Qualitative Study in Selected Counties in South Sudan
}

\author{
David Majuch Kunjok ${ }^{1}$, Paulo Okech. Ajak ${ }^{1}$, Atem Agot Deng ${ }^{2}$, Atem Nathan Anyuon ${ }^{3}$, Philip Malong Thiel ${ }^{4}$, \\ Deng Mawien Deng ${ }^{4} \&$ Kuol Manyang Diing ${ }^{4}$ \\ ${ }^{1}$ African Field Epidemiology Network, Juba, South Sudan \\ ${ }^{2}$ UNICEF, South Sudan \\ ${ }^{3}$ Ministry of Health, Directorate of Primary Health care, South Sudan \\ ${ }^{4}$ State Ministry of Health, Northern Bahr el Ghazal State, South Sudan \\ Correspondence: David Majuch Kunjok, African Field Epidemiology Network, Juba, South Sudan.
}

Received: April 12, 2021 Accepted: July 8, 2021 Online Published: July 27, 2021

doi:10.5539/gjhs.v13n9p52 URL: https://doi.org/10.5539/gjhs.v13n9p52

\begin{abstract}
Background: Reducing vaccine-preventable diseases mortality and morbidity in non-industrialized countries requires the enforcement of robust immunization strategies aimed at increasing coverage and reducing dropouts and missed immunization opportunities. Attaining high $(>80 \%)$ immunization coverage with a low drop-out rate in South Sudan has been challenging because of the program's high defaulting rates. This study aimed to determine the reasons for poor accessibility and utilization of immunization services in counties earmarked for Fragility, Emergency and Refugees (FER) in South Sudan.
\end{abstract}

Methods: A descriptive phenomenological study design was conducted across four counties of Northern Bahr El Ghazal, South Sudan, between May 2019 and December 2020 in which 42 focused group discussions and key-informant interviews involving the community and primary healthcare centers and units were conducted. Relevant EPI (Expanded program on immunization) tools were reviewed and data were analyzed using thematic analysis.

Results: The main reasons identified were negative attitudes towards healthcare workers and immunization services, competing priorities of the caregivers, delayed opening of the immunization sessions, insufficient cold chain facilities, inadequate knowledge and information about immunization services, and non-availability of vaccines at the health facility.

Conclusions: A plan to supply adequate vaccines and related supplies to the counties by identifying stock levels in time must be a priority. Health facility micro-plan development and implementation should be supported by increased funding for the implementation of outreach and mobile sessions to reach missed children, intensified door-to-door health awareness, and regular community meetings to increase vaccine uptake.

Keywords: accessibility, determinants, immunization, utilization, South Sudan

\section{Background}

Immunization has been one of the most economical public health measures that have significantly contributed to reducing child morbidity, mortality, and disability. Immunization is a key strategy in achieving Sustainable Development Goal (SDG) number three-reduction of under-five mortality to below 25/1000 live births by 2013 (WHO, 2013). The World Health Organization (WHO) reports of 2018 suggest that approximately 2.5 million child and 6 million adult deaths are prevented annually through immunization programs (WHO, 2017). Regardless of these attainments, low-income countries continue to experience vaccine-preventable diseases (VPDs) outbreaks (WHO, 2018). Timely vaccination and completion of immunization schedules are mandatory in controlling VPDs in Sub-Saharan Africa (Lydon et al., 2014; Janusz et al., 2020; Cherian et al., 2020).

Vaccination became the backbone of public health interventions when WHO launched the Expanded Programme on Immunization (EPI) in 1974 to help member states expand on immunization and surveillance programs against measles, poliomyelitis, tuberculosis, diphtheria, pertussis, and tetanus (WHO, 2018; Hwang et al., 2020). Since then significant progress has been achieved in upgrading vaccination coverage for six major vaccine-preventable 
diseases: pertussis, childhood tuberculosis, tetanus, polio, measles, and diphtheria in Africa using an equitable and cost-effective approach (WHO, UNICEF, 2018). The World Health Assembly endorsed the Global Vaccine Action Plan in 2012 to strengthen routine immunization and ensure improved access, and the use of routine immunization (RI) services as one of its guiding principles. However, about $70 \%$ of children with incomplete vaccination schedules were from only 10 countries in the world, indicating disparities in vaccination coverage among countries. Two-thirds of these countries achieved the Global Vaccine Action Plan target of $90 \%$, while the other one-third achieved $<80 \%$ of the diphtheria-tetanus-pertussis three (DTP3) coverage in districts, further corroborating the evidence of disparity (WHO, 2017; WHO, 2018). Nevertheless, this improvement has been due to the international efforts aimed at advancing the quality of immunization services, which include the Universal Childhood Immunization Initiative, the Global Alliance for Vaccines and Immunization (GAVI), the Sustainable Development Goals (SDGs), the Global Immunization Vision and Strategy (GIVS), and the Global Vaccine Action Plan (GVAP). These initiatives combined with WHO's African Region expanded program on immunization (EPI) - strategic plan of action for 2000 and 2014, the Reach Every District (RED) approach, and the national immunization programs have contributed to raising Africa's immunization coverage for DTP3 from $57 \%$ in 2000 to over $80 \%$ in 2017 (WHO, 2017).

In 2019, 116 million infants received basic vaccines globally (WHO, 2019,) which accounts for about $84 \%$ of the pediatric population of the world. Still, about 19.7 million infants remain unvaccinated, 6.2 million of which live in the Democratic Republic of Congo, Ethiopia, and Nigeria, (in the WHO African Region). An estimated 14 million infants out of the million surviving infants in 2019 never received their third dose of the DTP vaccine. Approximately $60 \%$ of these children are from Chad, the Democratic Republic of the Congo, Ethiopia, India, Indonesia, Mexico, Nigeria, South Africa, and South Sudan. Likewise, in poor, remote, and inaccessible areas of the African region, only one-in-twenty children had access to vaccination (Restrepo-Méndez et al., 2016; WHO, 2019).

The immunization program for South Sudan was established in 2005 after the signing of a comprehensive peace agreement and established an EPI. A year later, the autonomous government of Southern Sudan published the first policy documents 'Health Policy, 2007-2011' and the 'Basic Package of Health and Nutrition Services' (MOH, 2017). The Ministry Of Health, South Sudan used these policy documents as a cornerstone to prepare the EPI program 2011-2016 for a Comprehensive Multi-Year Plan (cMYP) for Immunization (MOH, 2017). Despite these efforts, there has been a recent progressive declination in the immunization performance in South Sudan, with routine immunization (pentavalent-3) declining from 71\% in 2012 to $55 \%$ in 2013 and reducing further to $26 \%$ in 2016. Consequently, only 9 out of the 80 counties (11\%) were able to achieve vaccination coverage of $80 \%$ in 2016 A 2017 EPI survey in South Sudan indicated that $18.9 \%$ of children under 1 year of age were fully immunized. Immunization coverage estimates by card and history were higher (49.1\%) compared to coverage by card alone (20.9\%). The dropout rate decreased from $20 \%$ in 2014 and $23.7 \%$ in 2016 to $16.8 \%$ Pentavalent 1 - Measles and $12.9 \%$ Pentavalent (Penta 1) 1- Pentavalent (Penta 3) respectively against the standard 10\% (MOH, 2018). South Sudan is still classified as facing a medium to high risk for polio outbreaks. Likewise, by $2017,48.7 \%$ of children were vaccinated against measles, and so, only a few counties reached the desired coverage of $\geq 80 \%$ and above to mitigate measles outbreaks. The foremost challenge faced by most communities is a lack of access and the ability to utilize immunization services. The set targets for Penta 3 and Penta 1 to Penta 3 dropout have not been achieved. In this regard, this study aims to determine the reasons for poor accessibility and utilization of immunization services in counties earmarked for Fragility, Emergency and Refugees (FER) in South Sudan (MOH, 2017).

\section{Methods and Materials}

\subsection{Study Population and Setting}

The study was conducted in the state of Northern Bahr el Ghazal (NBGS), one of the ten states in the Republic of South Sudan. The state borders Warrap to the southeast, Western Bahr el Ghazal state to the southwest, and Sudan to the northwest. According to the South Sudan Bureau of statistics (2020), Northern Bahr el Ghazal has a projected population of 1,253,442 (NBS, 2008), of which $5 \%$ of the population $(62,672)$ are under 1 year of age, $21 \%(263,223)$ under 5 years of age, $49 \%(614,187)$ are under 15 years of age, and the rest $25 \%(313,361)$ are women of reproductive age (WRA). The state has 5 counties and 38 administrative units after the county called the payams. The study focused on counties receiving FER funding due to their high number of unvaccinated children.

The Penta 1 performance for the NBGS as of 2020 is $82 \%$ coverage, suggesting that the communities have good access to immunization services. However, the Penta 3 coverage as of 2020 is $67 \%$ and the dropout rate (DOR) is $18 \%$, indicating poor utilization of immunization services. A total of 12,496 targeted children had not received Penta 1 dose and 10,299 children dropped out by the end of 2020 (MOH, 2020). Northern Bahr el Ghazal state has 
had influx of internal displaced persons (IDPs) from neighboring states and countries with frequent population movement. The state is bordering Sudan and Central African Republic. In addition, the state experiences seasonal flooding.

\subsection{Study Design}

A descriptive phenomenological study design was employed to understand the reasons for poor accessibility and utilization of immunization services among caregivers or mothers of children under 1 year of age, community leaders, and healthcare providers in the FER-earmarked counties and acquired the participants' perceptions and experiences. To interpret different themes in this study, a holistic approach was pursued presuming an interactive and inseparable relationship between the researcher and participants. Data were collected using in-depth, interviews and focused group discussions guided with open-ended questions. The qualitative data obtained were analyzed using thematic analysis.

\subsection{Selection Criteria and Participant Sampling}

The study was conducted between May 2019 and December 2020 to cover health facilities selected based on the problem analysis of utilization and accessibility. Health facilities with low utilization and poor accessibility were prioritized and their catchment population was subsequently selected using purposive sampling for focused group discussion. Caregivers or mothers above 18 years who lived within the health facility catchment area for more than a year, community leaders, and healthcare providers were considered the respondents of the study. A proposed sample of 10-15 caregivers and/or mothers and community leaders for focused group discussion and 7 key informants was decided for data collection. The potential participants were invited for an interview, while a letter of invitation containing details of the study had been sent to the county authorities prior. On the day of the interview, the purpose of the study was explained to all participants. The total number of study participants was 22 and all participants consented to participate in the study. Forty (40) health facilities in four counties with poor access and poor utilization of immunization activities in Northern Bahr el Ghazal State were prioritized (Tables 1, $2,3 \& 4$ ). Poor access was indicated by Pental coverage of below $80 \%$, and high dropout rate was indicated by over $10 \%$ DOR rate. The health facilities with high number of unvaccinated children were given first priority and the ones with low number of unvaccinated children were accorded the next priority level (Tables 1, 2, $3 \& 4$ ).

Table 1. Health facilities selected for the study in Aweil Centre, Northern Bahr el Ghazal 2020

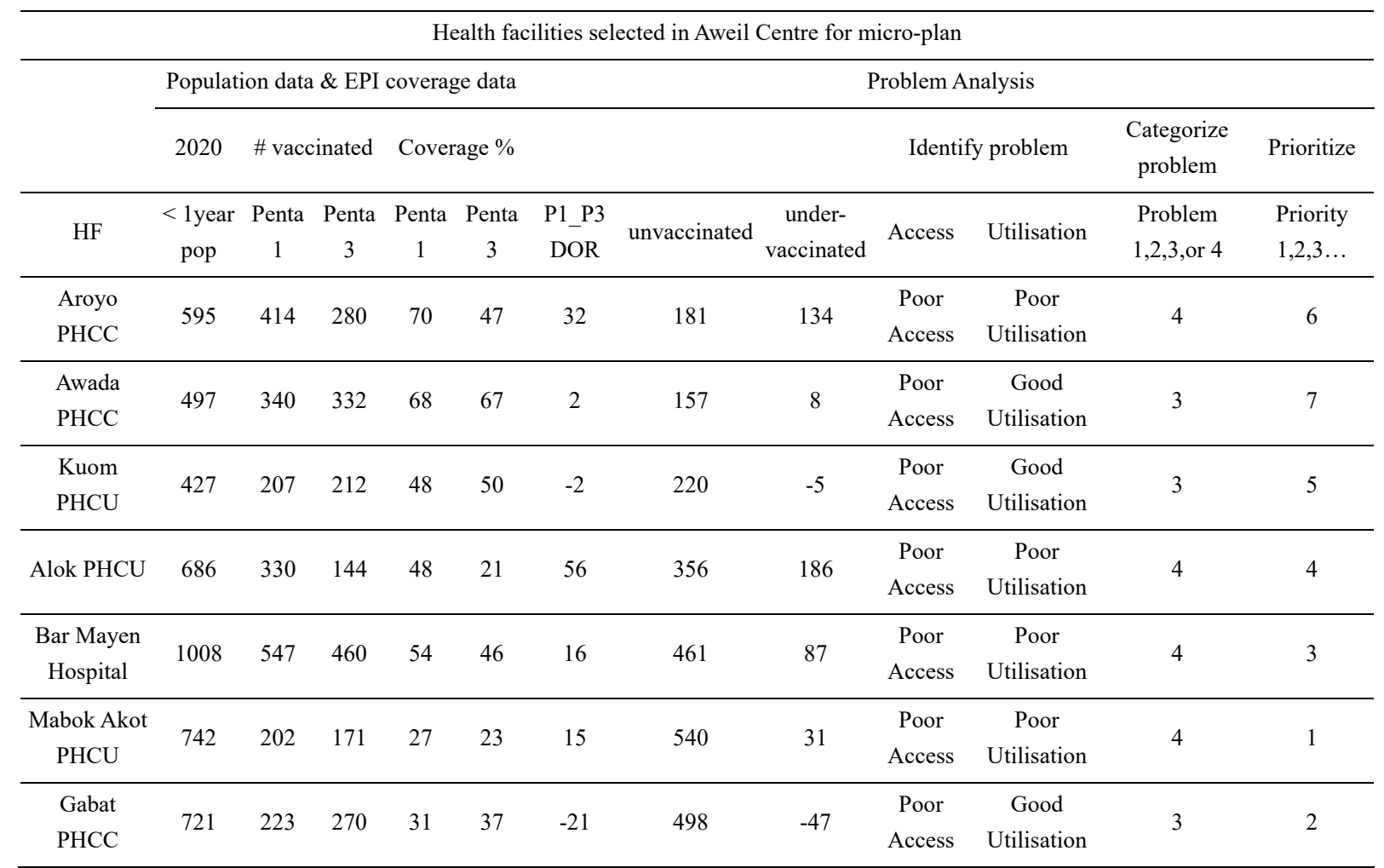

Source: MOH (2020). Definition: PHCC; Primary Health Care Centre, PHCU; Primary Health Care Unit. 
Table 2. Health facilities selected for the study in Aweil East, Northern Bahr el Ghazal 2020

\begin{tabular}{|c|c|c|c|c|c|c|c|c|c|c|c|c|}
\hline \multicolumn{13}{|c|}{ Health facilities selected in Aweil East for micro-plan } \\
\hline & \multicolumn{5}{|c|}{$\begin{array}{l}\text { Population data \& EPI coverage } \\
\text { data }\end{array}$} & \multicolumn{7}{|c|}{ Problem Analysis } \\
\hline & 2020 & \# vace & cinated & Cover & rage $\%$ & & & & Identif & y problem & $\begin{array}{l}\text { Categorize } \\
\text { problem }\end{array}$ & Prioritize \\
\hline $\mathrm{HF}$ & $\begin{array}{c}< \\
\text { lyear } \\
\text { pop }\end{array}$ & $\begin{array}{c}\text { Penta } \\
1\end{array}$ & $\begin{array}{c}\text { Penta } \\
3\end{array}$ & $\begin{array}{c}\text { Penta } \\
1\end{array}$ & $\begin{array}{c}\text { Penta } \\
3\end{array}$ & $\begin{array}{l}\text { P1_P3 } \\
\text { DOR }\end{array}$ & unvaccinated & under-vaccinated & Access & Utilisation & $\begin{array}{l}\text { Problem } \\
1,2,3, \text { or } 4\end{array}$ & $\begin{array}{l}\text { Priority } \\
1,2,3 \ldots\end{array}$ \\
\hline $\begin{array}{l}\text { Mangok } \\
\text { PHCU }\end{array}$ & 1999 & 421 & 393 & 21 & 20 & 7 & 1578 & 28 & $\begin{array}{c}\text { Poor } \\
\text { Access }\end{array}$ & $\begin{array}{c}\text { Good } \\
\text { Utilisation }\end{array}$ & 3 & \\
\hline $\begin{array}{c}\text { Manyiel } \\
\text { PHCU }\end{array}$ & 1394 & 218 & 153 & 16 & 11 & 30 & 1176 & 65 & $\begin{array}{c}\text { Poor } \\
\text { Access }\end{array}$ & $\begin{array}{c}\text { Poor } \\
\text { Utilisation }\end{array}$ & 4 & 1 \\
\hline $\begin{array}{l}\text { Malual bai } \\
\text { PHCC }\end{array}$ & 998 & 275 & 166 & 28 & 17 & 40 & 723 & 109 & $\begin{array}{c}\text { Poor } \\
\text { Access }\end{array}$ & $\begin{array}{c}\text { Poor } \\
\text { Utilisation }\end{array}$ & 4 & 2 \\
\hline $\begin{array}{l}\text { Tit-Chok } \\
\text { PHCU }\end{array}$ & 1032 & 347 & 350 & 34 & 34 & -1 & 685 & -3 & $\begin{array}{c}\text { Poor } \\
\text { Access }\end{array}$ & $\begin{array}{c}\text { Good } \\
\text { Utilisation }\end{array}$ & 3 & 3 \\
\hline $\begin{array}{c}\text { Madhol } \\
\text { PHCU }\end{array}$ & 888 & 222 & 213 & 25 & 24 & 4 & 666 & 9 & $\begin{array}{l}\text { Poor } \\
\text { Access }\end{array}$ & $\begin{array}{c}\text { Good } \\
\text { Utilisation }\end{array}$ & 3 & 4 \\
\hline $\begin{array}{l}\text { Yargot } \\
\text { PHCU }\end{array}$ & 834 & 280 & 209 & 34 & 25 & 25 & 554 & 71 & $\begin{array}{c}\text { Poor } \\
\text { Access }\end{array}$ & $\begin{array}{c}\text { Poor } \\
\text { Utilisation }\end{array}$ & 4 & 5 \\
\hline $\begin{array}{c}\text { Malualkon } \\
\text { Hospital }\end{array}$ & 1339 & 825 & 701 & 62 & 52 & 15 & 514 & 124 & $\begin{array}{c}\text { Poor } \\
\text { Access }\end{array}$ & $\begin{array}{c}\text { Poor } \\
\text { Utilisation }\end{array}$ & 4 & 6 \\
\hline $\begin{array}{l}\text { Wunlang } \\
\text { PHCU }\end{array}$ & 803 & 297 & 317 & 37 & 39 & -7 & 506 & -20 & $\begin{array}{c}\text { Poor } \\
\text { Access }\end{array}$ & $\begin{array}{c}\text { Good } \\
\text { Utilisation }\end{array}$ & 3 & 7 \\
\hline $\begin{array}{l}\text { Wanyjok } \\
\text { PHCC }\end{array}$ & 1116 & 694 & 535 & 62 & 48 & 23 & 422 & 159 & $\begin{array}{c}\text { Poor } \\
\text { Access }\end{array}$ & $\begin{array}{c}\text { Poor } \\
\text { Utilisation }\end{array}$ & 4 & 8 \\
\hline $\begin{array}{l}\text { Ameth Akok } \\
\text { PHCU }\end{array}$ & 694 & 283 & 175 & 41 & 25 & 38 & 411 & 108 & $\begin{array}{c}\text { Poor } \\
\text { Access }\end{array}$ & $\begin{array}{c}\text { Poor } \\
\text { Utilisation }\end{array}$ & 4 & 9 \\
\hline $\begin{array}{c}\text { Gordhim TB } \\
\text { Hosp }\end{array}$ & 632 & 259 & 186 & 41 & 29 & 28 & 373 & 73 & $\begin{array}{c}\text { Poor } \\
\text { Access }\end{array}$ & $\begin{array}{c}\text { Poor } \\
\text { Utilisation }\end{array}$ & 4 & 10 \\
\hline Atuet PHCU & 676 & 324 & 299 & 48 & 44 & 8 & 352 & 25 & $\begin{array}{c}\text { Poor } \\
\text { Access }\end{array}$ & $\begin{array}{c}\text { Good } \\
\text { Utilisation }\end{array}$ & 3 & 11 \\
\hline $\begin{array}{l}\text { Baach } \\
\text { PHCU }\end{array}$ & 437 & 102 & 76 & 23 & 17 & 25 & 335 & 26 & $\begin{array}{c}\text { Poor } \\
\text { Access }\end{array}$ & $\begin{array}{c}\text { Poor } \\
\text { Utilisation }\end{array}$ & 4 & 12 \\
\hline
\end{tabular}

Source: MOH (2020). Definition: PHCC; Primary Health Care Centre, PHCU; Primary Health Care Unit. 
Table 3. Health facilities selected for the study in Aweil West, Northern Bahr el Ghazal 2020

\begin{tabular}{|c|c|c|c|c|c|c|c|c|c|c|c|c|}
\hline \multicolumn{13}{|c|}{ Aweil West Selected HFs for Micro-plan } \\
\hline & \multicolumn{5}{|c|}{$\begin{array}{l}\text { Population data \& EPI coverage } \\
\text { data }\end{array}$} & \multicolumn{7}{|c|}{ Problem Analysis } \\
\hline & 2020 & \# vacc & cinated & Cover & rage $\%$ & & & & Identi & fy problem & $\begin{array}{l}\text { Categorize } \\
\text { problem }\end{array}$ & Prioritize \\
\hline $\mathrm{HF}$ & $\begin{array}{l}<1 \text { year } \\
\text { pop }\end{array}$ & $\begin{array}{c}\text { Penta } \\
1\end{array}$ & $\begin{array}{c}\text { Penta } \\
3\end{array}$ & $\begin{array}{c}\text { Penta } \\
1\end{array}$ & $\begin{array}{c}\text { Penta } \\
3\end{array}$ & $\begin{array}{l}\text { P1_P3 } \\
\text { DOR }\end{array}$ & unvaccinated under- & r-vaccinated & Access & Utilisation & $\begin{array}{l}\text { Problem } \\
1,2,3, \text { or } 4\end{array}$ & $\begin{array}{l}\text { Priority } \\
1,2,3 \ldots\end{array}$ \\
\hline Aguat PHCU & 315 & 149 & 139 & 47 & 44 & 7 & 166 & 10 & $\begin{array}{c}\text { Poor } \\
\text { Access }\end{array}$ & $\begin{array}{c}\text { Good } \\
\text { Utilisation }\end{array}$ & 3 & 10 \\
\hline $\begin{array}{l}\text { Aluel Acot } \\
\text { PHCU }\end{array}$ & 475 & 138 & 110 & 29 & 23 & 20 & 337 & 28 & $\begin{array}{c}\text { Poor } \\
\text { Access }\end{array}$ & $\begin{array}{c}\text { Poor } \\
\text { Utilisation }\end{array}$ & 4 & 6 \\
\hline $\begin{array}{l}\text { Angot Leek } \\
\text { PHCU }\end{array}$ & 637 & 296 & 406 & 46 & 64 & -37 & 341 & -110 & $\begin{array}{c}\text { Poor } \\
\text { Access }\end{array}$ & $\begin{array}{c}\text { Good } \\
\text { Utilisation }\end{array}$ & 3 & 5 \\
\hline $\begin{array}{c}\text { Anyopjang } \\
\text { PHCU }\end{array}$ & 493 & 210 & 123 & 43 & 25 & 41 & 283 & 87 & $\begin{array}{c}\text { Poor } \\
\text { Access }\end{array}$ & $\begin{array}{c}\text { Poor } \\
\text { Utilisation }\end{array}$ & 4 & 8 \\
\hline $\begin{array}{l}\text { Maleka Dera } \\
\text { PHCU }\end{array}$ & 486 & 261 & 204 & 54 & 42 & 22 & 225 & 57 & $\begin{array}{c}\text { Poor } \\
\text { Access }\end{array}$ & $\begin{array}{c}\text { Poor } \\
\text { Utilisation }\end{array}$ & 4 & 9 \\
\hline $\begin{array}{c}\text { Marial Bai } \\
\text { PHCC }\end{array}$ & 1146 & 740 & 674 & 65 & 59 & 9 & 406 & 66 & $\begin{array}{c}\text { Poor } \\
\text { Access }\end{array}$ & $\begin{array}{c}\text { Good } \\
\text { Utilisation }\end{array}$ & 3 & 4 \\
\hline $\begin{array}{l}\text { Nyamlel } \\
\text { PHCC }\end{array}$ & 1312 & 860 & 202 & 66 & 15 & 77 & 452 & 658 & $\begin{array}{c}\text { Poor } \\
\text { Access }\end{array}$ & $\begin{array}{c}\text { Poor } \\
\text { Utilisation }\end{array}$ & 4 & 3 \\
\hline $\begin{array}{l}\text { Nyinbouli } \\
\text { PHCC }\end{array}$ & 900 & 311 & 173 & 35 & 19 & 44 & 589 & 138 & $\begin{array}{c}\text { Poor } \\
\text { Access }\end{array}$ & $\begin{array}{c}\text { Poor } \\
\text { Utilisation }\end{array}$ & 4 & 2 \\
\hline $\begin{array}{l}\text { Riangangon } \\
\text { PHCU }\end{array}$ & 535 & 248 & 220 & 46 & 41 & 11 & 287 & 28 & $\begin{array}{c}\text { Poor } \\
\text { Access }\end{array}$ & $\begin{array}{c}\text { Poor } \\
\text { Utilisation }\end{array}$ & 4 & 7 \\
\hline $\begin{array}{l}\text { Wedweil } \\
\text { PHCU }\end{array}$ & 1177 & 279 & 265 & 24 & 23 & 5 & 898 & 14 & $\begin{array}{c}\text { Poor } \\
\text { Access }\end{array}$ & $\begin{array}{c}\text { Good } \\
\text { Utilisation }\end{array}$ & 3 & 1 \\
\hline
\end{tabular}

Source: MOH (2020). Definition: PHCC; Primary Health Care Centre, PHCU; Primary Health Care Unit. 
Table 4. Health facilities selected for the study in Aweil North, Northern Bahr el Ghazal 2020

\begin{tabular}{|c|c|c|c|c|c|c|c|c|c|c|c|c|}
\hline \multicolumn{13}{|c|}{ Aweil North Selected HFs Micro-Plan } \\
\hline & \multicolumn{6}{|c|}{ Population data \& EPI coverage data } & \multicolumn{5}{|c|}{ Problem Analysis } & \multirow[b]{2}{*}{ Prioritiz } \\
\hline & 2020 & \# vac & cinated & Cove & rage $\%$ & & & & Identi & fy problem & $\begin{array}{c}\text { Categorize } \\
\text { problem }\end{array}$ & \\
\hline $\mathrm{HF}$ & $\begin{array}{c}< \\
\text { 1year } \\
\text { pop }\end{array}$ & $\begin{array}{c}\text { Penta } \\
1\end{array}$ & $\begin{array}{c}\text { Penta } \\
3\end{array}$ & $\begin{array}{c}\text { Pent } \\
\text { a } 1\end{array}$ & $\begin{array}{c}\text { Penta } \\
3\end{array}$ & $\begin{array}{c}\text { P1_P3 } \\
\text { DOR }\end{array}$ & unvaccinated & under-vaccinated & Access & Utilisation & $\begin{array}{l}\text { Problem } \\
1,2,3 \text {,or } 4\end{array}$ & $\begin{array}{l}\text { Priority } \\
1,2,3 \ldots\end{array}$ \\
\hline $\begin{array}{l}\text { Arieth } \\
\text { PHCU }\end{array}$ & 544 & 344 & 386 & 63 & 71 & -12 & 200 & -42 & $\begin{array}{c}\text { Poor } \\
\text { Access }\end{array}$ & $\begin{array}{c}\text { Good } \\
\text { Utilisation }\end{array}$ & 3 & 6 \\
\hline $\begin{array}{c}\text { Gok Machar } \\
\text { PHCC }\end{array}$ & 1080 & 642 & 560 & 59 & 52 & 13 & 438 & 82 & $\begin{array}{c}\text { Poor } \\
\text { Access }\end{array}$ & $\begin{array}{c}\text { Poor } \\
\text { Utilisation }\end{array}$ & 4 & 1 \\
\hline $\begin{array}{c}\text { Jaac PPF } \\
\text { PHCU }\end{array}$ & 300 & 165 & 125 & 55 & 42 & 24 & 135 & 40 & $\begin{array}{c}\text { Poor } \\
\text { Access }\end{array}$ & $\begin{array}{c}\text { Poor } \\
\text { Utilisation }\end{array}$ & 4 & 10 \\
\hline Kajik PHCU & 474 & 217 & 228 & 46 & 48 & -5 & 257 & -11 & $\begin{array}{c}\text { Poor } \\
\text { Access }\end{array}$ & $\begin{array}{c}\text { Good } \\
\text { Utilisation }\end{array}$ & 3 & 5 \\
\hline $\begin{array}{c}\text { Majak Bai } \\
\text { PHCC }\end{array}$ & 550 & 242 & 194 & 44 & 35 & 20 & 308 & 48 & $\begin{array}{c}\text { Poor } \\
\text { Access }\end{array}$ & $\begin{array}{c}\text { Poor } \\
\text { Utilisation }\end{array}$ & 4 & 4 \\
\hline $\begin{array}{c}\text { Mayen Ulem } \\
\text { PHCU }\end{array}$ & 772 & 366 & 291 & 47 & 38 & 20 & 406 & 75 & $\begin{array}{c}\text { Poor } \\
\text { Access }\end{array}$ & $\begin{array}{c}\text { Poor } \\
\text { Utilisation }\end{array}$ & 4 & 2 \\
\hline $\begin{array}{c}\text { Mayom } \\
\text { Adhal } \\
\text { PHCU }\end{array}$ & 326 & 156 & 123 & 48 & 38 & 21 & 170 & 33 & $\begin{array}{c}\text { Poor } \\
\text { Access }\end{array}$ & $\begin{array}{c}\text { Poor } \\
\text { Utilisation }\end{array}$ & 4 & 7 \\
\hline $\begin{array}{c}\text { Warapei } \\
\text { PHCC }\end{array}$ & 400 & 242 & 181 & 61 & 45 & 25 & 158 & 61 & $\begin{array}{c}\text { Poor } \\
\text { Access }\end{array}$ & $\begin{array}{c}\text { Poor } \\
\text { Utilisation }\end{array}$ & 4 & 9 \\
\hline $\begin{array}{c}\text { Wargeng } \\
\text { PHCU }\end{array}$ & 344 & 209 & 135 & 61 & 39 & 35 & 135 & 74 & $\begin{array}{c}\text { Poor } \\
\text { Access }\end{array}$ & $\begin{array}{c}\text { Poor } \\
\text { Utilisation }\end{array}$ & 4 & 10 \\
\hline $\begin{array}{l}\text { Wathok } \\
\text { PHCU }\end{array}$ & 496 & 112 & 66 & 23 & 13 & 41 & 384 & 46 & $\begin{array}{c}\text { Poor } \\
\text { Access }\end{array}$ & $\begin{array}{c}\text { Poor } \\
\text { Utilisation }\end{array}$ & 4 & 3 \\
\hline
\end{tabular}

Source: MOH (2020). Definition: PHCC; Primary Health Care Centre, PHCU; Primary Health Care Unit.

\subsection{Data Collection}

A conducive and quiet venue was identified at the health facility or community facilities premises for conducting focused group discussions and key informant interviews. Before beginning the interview, the interviewers introduced themselves, read and explained the details of the consent form, and requested participants' verbal consent for the interview and its audio recording. A pre-tested in-depth interview guide, consisting of thematic open-ended questions, was used to collect data from key informants. Then, the interviewer supplemented the interview guide with follow-up questions, paraphrasing, and/or adding short silence breaks to further the discussion, or probe the study participant's comments. Twenty-two (22) interview notes were taken to supplement the audio recordings to capture all possible impressions and observations. The audio recordings were backed up on personal electronic devices to prevent data loss.

\subsection{Data Analysis}

The devices containing audio recordings were kept in a secure place and audio files were protected with a strong password. The interviews were conducted in Dinka and Luo dialects which were spoken by the majority of study participants. The audio data were transcribed verbatim to English using thematic analysis. After transcription of the audio file, the data was saved on an external hard drive and both the audio files were kept safe which would be deleted after one year from the date of the study. The manifest and latent content analyses of qualitative data were employed wherever visible and obvious components of the text were described. Supplemental notes for each interview were revised after each day of the interview and unnecessary terminologies were removed. The 
transcribed notes were then read through to ensure meaning out of them. Sentences or phrases that contained similar aspects were merged to form one theme. The themes were then summarized to remove redundancy and repetitions while preserving the original meaning of the text.

\section{Results}

\subsection{Participant Characteristics and Key Themes}

The interviewers conducted 15 focused group discussions (FGDs) with mothers and caregivers, 5 FGDs with healthcare workers, and 7 key informants across the four counties that were earmarked for health facility micro-plan development in the Northern Bahr el Ghazal state. Each FGD comprised 10-15 participants, and consequently, about 70 mothers and caregivers, and 42 healthcare workers were interviewed during the study. The healthcare workers participating in FGDs were from different backgrounds at the health facility, while the key informants came from both the health facility and the community.

The main themes from the thematic analysis of the data include perceptions of healthcare workers, integration of immunization with other primary care services, staffing of healthcare workers, availability of vaccines at the health facility, and lack of immunization information. The findings are summarized by key themes in the subsequent paragraphs and verbatim quotes recorded during the interview and FGDs are also included.

\subsection{Perceptions of Vaccination}

The participants expressed mixed reactions - while some had negative experiences and attitudes towards healthcare workers and immunization services, other mothers and caregivers believed that healthcare workers were generally knowledgeable: "Sometimes the vaccinators are available at the health facility some other we don't get them" (Caregiver). The vaccinators/healthcare workers and the key informants expressed a similar sentiment with perceptions of caregiver dissatisfaction: "Some of our women, including my wife, if you tell them to go for ANC or take a child for vaccination, they don't go. This is not something we can count on the service providers." (Key Informant). "Mothers don't bring their children for vaccination and......", "yes, (the other interjected in agreement)" (Vaccinator).

\subsection{Health Systems and Health Care Workers Factors}

Many participants noted that there was a need to address some of these problems. Besides, long distances limit the caregivers' and mothers' accessibility to the immunization services, but they do come whenever they get a chance to do so: "Long-distance to the health facility is one major challenge....." (Key informant). Another concern was the cold chain facility. When a woman comes to the health facility and finds out that there are no vaccines available today, they don't return as advised. Others take 2-3 months before returning." "There is a challenge where some of the health facilities under government have been closed down. These created a challenge of access as some of the remaining facilities are farfetched" (Key informant).

\subsection{Vaccines Supply Problems}

"We come to the health facility and find they are not working, because they say vaccines are not available" (Caregiver). "So next time I will not come because I will find the same situation", another caregiver added. This deficiency is compounded by out-of-stock vaccines in the health facilities and beyond-limit vaccination days for antigens, such as for BCG and measles vaccines: "Vaccines are given on a specific day" (Caregiver).

The key informants discussed various reasons for vaccine stock-out, which included lack of coordination with various agencies, delay in vaccine delivery to health facilities from the county cold-chain store, and lack of transportation funds. Logistic challenges were also discussed, such as the unavailability of bicycles for supervision and outreaches in distant health facilities: "Our facility covers a very wide area. Our vaccinators ought to have bicycles to help them conduct outreach services" (Key informant). Vaccines stock and other supplies and cold chain equipment were also some of the problems identified by the participants: "Shortage of cold chain in our facility is the major challenge. We, community members who understand the importance of immunization will help mobilize our community if we have a cold chain here in our facility" (Key informant). A vaccinator added, "For example, there was a time we go for three months without $B C G$, some of them never have their BCG vaccination until today" The health workers also added a breakdown of their refrigerator: "sometimes, the refrigerator is not working well and the technician is not available to fix it, form the national level" (Key informant).

The limited vaccine stocks discouraged caregivers or mothers to return for vaccination: "the mothers will bring their children on the day of visit but not return; they will as well tell the members of their community that there are no vaccines in the health facility" (Vaccinator). 


\subsection{Awareness about the Benefits of Immunization}

Surprisingly, some caregivers had negative attitudes towards the importance of vaccines and expressed competing for priorities to take their children for vaccination: "....they say if I go and spend the whole day in the line just for my child to receive vaccine dose, where will I get food for them at the end of the day?" (Key informant). Also, rumors and misconceptions about adverse events were common among the caregivers/mothers: "My child got sick after receiving the first dose" (Caregiver).

\subsection{Poor Referral for Immunization Services}

Some key informants and vaccinators reported that mothers and caregivers bring their children to the health facilities only for nutrition services: "Our women only go for services where they can have direct benefits. They don't understand the importance of immunization. When you tell a woman with a child who is not malnourished to go for vaccination, they ask what will be the benefit. They say if I go and spend the whole day in the line just for my child to receive vaccine dose, where will I get food for them at the end of the day?" Another added, "when there was a nutrition site here, we used to receive more children for routine EPI services. Little had we known that those children were attracted by the nutrition program?" "The presence of nutrition program here made many women come with their children where they could receive both the nutrition services and routine immunization program" (Key informant). These findings suggest that the integration of immunization services with other primary health care services can be decisive in improving immunization coverage.

Furthermore, consistency should be maintained across the health facilities in checking vaccination status on the child's health card. The ground situation revealed that the systems for monitoring the vaccination status lack uniformity in protocol across health facilities, as some of the key informants stated about checking the vaccination status of children at their visit to the health facility, while others checked it during the child's visit to nutrition services: "Many women come for nutrition services with their children but when we remind them to ensure they complete RI services, they ignore them. For example, one woman came with her child and when I told her to take the child for RI dose, she claimed that the child was sick and when I checked, the child was fine. I had to convince here."

Additionally, mothers and caregivers were dissatisfied with the long waiting-time due to the absence of a vaccinator in the health facility: "The vaccinator is not in the health facility or sometimes they are doing other work within the health facilities" (Caregivers/Mothers). "During outreach day, one of us remains in the health facility and the other goes for outreach, mothers will wait for a longer time and some don't come back for vaccination" (Vaccinator).

\subsection{Child Health Card}

Another important problem expressed by health workers/vaccinators was that mothers or caregivers do not carry the child's Health Card during their visit to the health facility: "Most women leave the immunization cards behind and use it as a trick to refuse routine immunization" (Vaccinator).

\subsection{Health Education (Lack of Information)}

The themes of health education and social mobilization were also discussed in the FGDs: "The women in our community are highly illiterate. If there is any support that you need from us, then we will support you. These messages have to be passed on Akolyam Radio." (Key informant). "Some women say that if a child is not malnourished then there is no reason to take that child to the health facility because they do not enroll healthy children for a nutrition program" (Key Informant). The health care workers suggested that health facilities should prioritize community-involvement in the immunization services planning: "Thank you all for coming. Some women give birth at the health facility and after one dose, they don't return. When they come for nutrition services, they should be asked to present an immunization card. Some men when they hear children crying at night after vaccination stop their wives because they don't understand it. This message has to be broadcast regularly on Akolyam to remind parents of the importance of the vaccine for children" (Key informant). "Immunization is important. One issue that needs to be stressed is that when a child receives the vaccine dose and develops some reactions then they think it's the vaccine that causes that. Many children have not completed their doses" (Key informant).

Both, the caregivers and the health worker, acknowledged the importance of health education: "The challenge for healthcare service uptake is a challenge for us as parents - both men and women. All of us are ignorant about the health of our children. Sometimes the father tells the mother to take the child to the health facility and the woman ends up not taking the child to the health facility. We need health education on this" (Caregiver). "Health education should also be provided for mothers to understand why their children need the vaccination" (Health worker). 


\subsection{Community-Involvement in Immunization Service}

Some health care workers raised notable concerns about the difficulties they faced while carrying out community mobilization: "When I go out on defaulter tracing, some parents claim that my child got sick after receiving the first dose. Others travel away from where their children received the first doses of vaccines" (Health worker). "The major challenge is that the health facility is cut off by the flood. Mobilizers have been going out to mobilize mothers and caregivers to bring children to the health facility for vaccination, but they don't turn up" (Health worker).

\section{Discussion}

This study reveals the ground-situation in one of the South Sudanese states, highlighting the reasons for poor accessibility and utilization of the existing immunization services. It embraces issues about the health systems and health workers, vaccine supply, awareness about immunization, the inconsistency in the referral system for immunization services, the consequent poor handling of the Child Health Card, and the important themes of health education and community involvement.

Lack of information with the mother/caregiver is a frequently reported factor resulting in poor exploitation and low accessibility of the available resources. Our results further corroborate this observation as a majority of the caregivers participating in our study were reportedly unaware of the benefits of immunization and the vaccination schedules. Similar observations were reported in previous studies that explored reasons for incomplete immunization and stated the lack of knowledge to be the main reason (Negussie et al., 2016; Animaw et al., 2013; Babriye et al., 2014, Etana et al., 2012). Likewise, a study conducted in Southern Ethiopia about defaulting from childhood immunization revealed that mothers were not sufficiently aware of the various operational aspects and schedules (Zewdie et al., 2016). Furthermore, it was seen that caregivers deliberately left their child's vaccination card at home to avoid vaccination. Zewdie et al. (2016) described that the mothers did not know what to do in the event the vaccination card was lost, and thus, they recommended that no child be denied vaccination when the mother fails to carry the child's health card to the health facility (Zewdie et al., 2016). Availability of the vaccination card improves the probability of the child getting immunized, besides ensuring continuity in availing immunization by the beneficiaries, as well as improving the validity by avoiding revaccinating (Itimi et al., 2012; Elizabeth et al., 2015). The Ministry of Health, South Sudan also recommends that every child gets vaccinated even when the caregiver fails to produce the vaccination card at the time of vaccination to reduce the missed opportunities for vaccination. Therefore, to tackle this lack of awareness and the unwillingness by caregivers/mothers to conform to the vaccination schedules and maintain the vaccination cards, there is a need to intensify health education in the community through innovative ways to reach out and create demand.

Another reason for the low utilization of immunization services was competing for priorities like income-generating activities to support their families than take their children for vaccination. These findings are similar to Babirye et al. (2011) and Biset et al. (2021), who have also revealed that competing priorities limited the mother's ability to complete the immunization schedule.

Our study also identified certain issues related to the existing health system that limit the full exploitation of these resources. The World Health Organization (WHO) recognizes factors related to the health system and health workers as the key barriers to low utilization of immunization services (WHO, 2013; Hailu et al., 2019). It was observed that distance was a significant factor responsible for the poor accessibility of immunization services. Abdulraheem et al. (2013) also reported similar results as the mothers found it difficult to commute/take the child to the health facility and hence opted to discontinue the immunization schedule. However, it is notable that the estimated distance to the health facility as described by the caregivers was not reliable because they could not accurately remember the distance they traveled to the health facility.

Our study also highlighted the weak state of health education sessions. Mothers who participated in the study were not sure about the aim of immunization, while some only visited the health facility to avail nutrition services for their children, which they believed was of immediate benefit. Zewdie et al. (2016) also disclosed that mothers lacked clear and quality information on scheduling, services planning, and benefits of vaccination owing to poor counseling, and improper, inadequate guidance regarding immunization. Adedemy et al. (2012) have also cited the same reasons for non-compliance. Another explanation for this could be attributed to poor handling of rumors by the health workers about the adverse effects following immunization, vaccine administration, and vaccine hesitancy related to multiple injections. Meanwhile studies have shown that health information from health workers is the most trusted by the community (Mishra et al., 2014; Wallace et al., 2018; Grant et al., 2017). Hence, inadequate knowledge within the workers of the existing health systems could setback the utilization and accessibility of immunization services (Li et al., 2020). 
Our study uncovered some disappointing facts as well. Negative attitudes by the vaccinators coupled with absence from the health facility led to mothers waiting for long hours. Maina et al. (2013) and Zewdie et al. (2016) have also documented negative views held by caregivers about the healthcare workers based on their management of the incoming people. Other studies have also noted that caregivers/mothers did not get a polite response from health care workers when they sought advice about their children getting missed vaccine doses (Babirye et al., 2014; Abdulraheem et al., 2011; Negussie et al., 2016). These findings underscore the fact that immunization-service providers must be trained adequately in the necessary knowledge-building activities to change this narrative. Besides, irregularity of the fixed and outreach sessions owing to absent vaccinators in the health facilities and a lack of transportation facilities also contributed to the poor accessibility and utilization. Irregularities in these activities and their importance to the beneficiaries can confuse them, leading to defaulting (Zewdie et al., 2016).

To counter the inadequacies in vaccine information, the key informants stressed the need to increase the use of radio to pass quality and reliable information. Radio systems have been established as a key medium for the dissemination of information about vaccination to improve vaccine uptake (MacDonald et al., 2015). It worth noting that the source of information used to influence the caregivers' choice should be selected carefully to improve the reach of immunization services. Also, providers must choose communication methods that further the aim of successful utilization of immunization services by the caregivers (Opel et al., 2013; Aregawi et al., 2017; Fite et al., 2019). Further, to achieve better utilization of immunization services, social mobilization structures embedded within the EPI should be strengthened to change social behavior hindering vaccine utilization by the beneficiaries. Additional efforts should be focused on building skills and knowledge of these social mobilizers (Ruso et al., 2015; Acharya et al., 2018; Li et al., 2020).

Besides the aforementioned revelations, the study also identified factors associated with vaccine availability, like logistic constraints and poor vaccine forcasting leading to stock-out, which hamper the routine immunization process. Li et al. (2020) and Etana et al. (2012) reported that vaccine stock-out has an impending effect to daunt caregivers from seeking immunization services from the nearby health facilities if they have had a previous experience of not having their children vaccinated due to unavailability (Wado et al., 2014; Adokiya et al., 2017; Butt et al., 2020). The strength of this current study was that, a holistic approach was pursued in which interactive and inseparable relationship between the researcher and participants was key to avoid researcher's bias. This also gained insights for the reasons for poor utilization and accessibility in depth. The limitation was that, this study did not account for exit interviews of the caregivers at the immunization units, and the impact of COVID-19 on immunization uptake in South Sudan. However, South Sudan immunization coverage in 2019 was $58 \%$ for Penta 3 compared to 2020 (MOH, 2019, 2020) which witnessed an increase to about 61\% for Penta 3 during COVID-19 pandemic. We could not, therefore, associate low utilization of immunization services to the pandemic. However, the impacts of the COVID_19 pandemic on the immunization programme, general health and the livelihoods of the people is a rife topic for subsequent studies.

\section{Conclusion}

The study highlights that low uptake of the immunization services by eligible children may be attributed to several factors, including negative attitudes towards healthcare workers and immunization service, competing priorities of the caregivers, delayed opening of the immunization sessions, insufficient cold chain facilities, inadequate knowledge about immunization services and schedules, and unavailability of vaccines at the health facility. To improve vaccine utilization and accessibility, health workers must develop their knowledge, attitudes, and practices to address these factors. A plan to supply adequate vaccines and related supplies to the counties must prioritize identifying stock levels in time to reduce lead time. Also, the health facility micro-plan development and implementation, as used in 80 counties in South Sudan (gold standard to identify missed children for immunization), must be supported by increased funding for implementation of outreach and mobile sessions, intensified door-to-door health awareness, and regular community meetings to increase uptake.

\section{Competing Interests Statement}

The authors declare that there are no competing or potential conflicts of interest.

\section{References}

Abdulraheem, I. S., Onajole, A. T., Jimoh, A. A. G., \& Oladipo, A. R. (2011). Reasons for incomplete vaccination and factors for missed opportunities among rural Nigerian children. Journal of Public Health and Epidemiology, 3(4), 194-203.

Acharya, P., Kismul, H., Mapatano, M. A., \& Hatløy, A. (2018). Individual-and community-level determinants of child immunization in the Democratic Republic of Congo:a multilevel analysis. PloS one, 13(8), e0202742. 
https://doi.org/10.1371/journal.pone.0202742

Adedemy, D. J., Noudamadjo, A., \& Agossou, J. (2015). Factors associated with drop-out between tuberculosis and measles immunization among infants in Parakou (Benin) in 2012. Pediatr Ther, 5(01). https://doi.org/10.4172/2161-0665.1000219

Adokiya, M. N., Baguune, B., \& Ndago, J. A. (2017). Evaluation of immunization coverage and its associated factors among children 12-23 months of age in Techiman Municipality,Ghana, 2016. Archives of Public Health, 75(1), 1-10. https://doi.org/10.1186/s13690-017-0196-6

Animaw, W., Taye, W., Merdekios, B., Tilahun, M., \& Ayele, G. (2014). Expanded program of immunization coverage and associated factors among children age 12-23 months in Arba Minch town and Zuria District, Southern Ethiopia, 2013. BMC public health, 14(1), 1-10. https://doi.org/10.1186/1471-2458-14-464

Aregawi, H. G., Gebrehiwot, T. G., Abebe, Y. G., Meles, K. G., \& Wuneh, A. D. (2017). Determinants of defaulting from completion of child immunization in Laelay Adiabo District, Tigray Region, Northern Ethiopia: A case-control study. PLoS One, 12(9), e0185533. https://doi.org/10.1371/journal.pone.0185533

Babirye, J. N., Rutebemberwa, E., Kiguli, J., Wamani, H., Nuwaha, F., \& Engebretsen, I. M. (2011). More support for mothers: a qualitative study on factors affecting immunisation behaviour in Kampala, Uganda. BMC public health, 11(1), 1-11. https://doi.org/10.1186/1471-2458-11-723

Biset, G., Woday, A., Mihret, S., \& Tsihay, M. (2021). Full immunization coverage and associated factors among children age 12-23 months in Ethiopia: systematic review and meta-analysis of observational studies. Human Vaccines \& Immunotherapeutics, 1-10. https://doi.org/10.1080/21645515.2020.1870392

Butt, M., Mohammed, R., Butt, E., Butt, S., \& Xiang, J. (2020). Why have immunization efforts in Pakistan failed to achieve global standards of vaccination uptake and infectious disease control?. Risk management and healthcare policy, 13, 111. https://doi.org/10.2147/RMHP.S211170

Cherian, T., \& Mantel, C. (2020). National immunization programmes. Bundesgesundheitsblatt-Gesundheitsforschunghttps://doi.org/10.1007/s00103-019-03062-1 Gesundheitsschutz, $\quad$ 63(1), $\quad 16$.

Elizabeth, K., George, K., Raphael, N., \& Moses, E. (2015). Factors influencing low immunization coverage among children between 12-23 months in East Pokot, Baringo Country, Kenya. Int J Vaccines Vaccin, 1(2), 00012. https://doi.org/10.15406/ijvv.2015.01.00012

Etana, B., \& Deressa, W. (2012). Factors associated with complete immunization coverage in children aged 12-23 months in Ambo Woreda, Central Ethiopia. BMC public health, 12(1), 1-9. https://doi.org/10.1186/1471-2458-12-566

Fite, R. O., \& Hailu, L. D. (2019). Immunization coverage of 12 to 23 months old children in Ethiopia. Journal of Public Health and Epidemiology, 11(1), 31-37. https://doi.org/10.5897/JPHE2018.1071

Grant, M., Wilford, A., Haskins, L., Phakathi, S., Mntambo, N., \& Horwood, C. M. (2017). Trust of community health workers influences the acceptance of community- based maternal and child health services. African journal of primary health care \& family medicine, $9(1), 1-8$. https://doi.org/10.4102/phcfm.v9i1.1281

Hailu, S., Astatkie, A., Johansson, K. A., \& Lindtjørn, B. (2019). Low immunization coverage in Wonago district, southern Ethiopia: a community-based cross-sectional study. PloS one, 14(7), e0220144. https://doi.org/10.1371/journal.pone.0220144

Hwang, A., Veira, C., Malvolti, S., Cherian, T., MacDonald, N., Steffen, C., ... \& Mantel, C. (2020). Global Vaccine Action Plan Lessons Learned II: Stakeholder Perspectives. Vaccine, 38(33),5372-5378. https://doi.org/10.1016/j.vaccine.2020.05.048

Itimi, K., Dienye, P. O., \& Ordinioha, B. (2012). Community participation and childhood immunization coverage: a comparative study of rural and urban communities of Bayelsa State, south-south Nigeria. Nigerian medical journal: journal of the Nigeria Medical Association, 53(1), 21. https://doi.org/10.4103/0300-1652.99826

Janusz, C. B., Frye, M., Mutua, M. K., Wagner, A. L., Banerjee, M., \& Boulton, M. L. (2021). Vaccine Delay and Its Association With Undervaccination in Children in Sub- Saharan Africa. American Journal of Preventive Medicine, 60(1), S53-S64. https://doi.org/10.1016/j.amepre.2020.10.003

Li, A. J., Tabu, C., Shendale, S., Okoth, P. O., Sergon, K., Maree, E., ... \& Ogbuanu, I. U. (2020). Qualitative insights into reasons for missed opportunities for vaccination in Kenyan health facilities. PloS one, 15(3), 
e0230783. https://doi.org/10.1371/journal.pone.0230783

Lydon, P., Gandhi, G., Vandelaer, J., \& Okwo-Bele, J. M. (2014). Health system cost of delivering routine vaccination in low-and lower-middle income countries: what is needed over the next decade?. Bulletin of the World Health Organization, 92, 382- 384. https://doi.org/10.2471/BLT.13.130146

MacDonald, N. E. (2015). Vaccine hesitancy: Definition, scope and determinants. Vaccine, 33(34), 4161-4164. https://doi.org/10.1016/j.vaccine.2015.04.036

Maina, L. C., Karanja, S., \& Kombich, J. (2013). Immunization coverage and its determinants among children aged 12-23 months in a peri-urban area of Kenya. Pan African Medical Journal, 14(1). https://doi.org/10.11604/pamj.2013.14.3.2181

Minor, P. D. (2012). The polio-eradication programme and issues of the end game. Journal of general virology, 93(3), 457-474. https://doi.org/10.1099/vir.0.036988-0

Mishra, A. (2014). 'Trust and teamwork matter': Community health workers' experiences in integrated service delivery in India. Global public health, 9(8), 960-974. https://doi.org/10.1080/17441692.2014.934877

Negussie, A., Kassahun, W., Assegid, S., \& Hagan, A. K. (2015). Factors associated with incomplete childhood immunization in Arbegona district, southern Ethiopia: a case- control study. BMC public health, 16(1), 1-9. https://doi.org/10.1186/s12889-015-2678-1

Opel, D. J., Heritage, J., Taylor, J. A., Mangione-Smith, R., Salas, H. S., DeVere, V., ... \& Robinson, J. D. (2013). The architecture of provider-parent vaccine discussions at health supervision visits. Pediatrics, 132(6), 1037-1046. https://doi.org/10.1542/peds.2013-2037

Restrepo-Méndez, M. C., Barros, A. J., Wong, K. L., Johnson, H. L., Pariyo, G., França, G. V., ... \& Victora, C. G. (2016). Inequalities in full immunization coverage: trends in low-and middle-income countries. Bulletin of the World Health Organization, 94(11), 794. https://doi.org/10.2471/BLT.15.162172

Russo, G., Miglietta, A., Pezzotti, P., Biguioh, R. M., Mayaka, G. B., Sobze, M. S., ... \& Rezza, G. (2015). Vaccine coverage and determinants of incomplete vaccination in children aged 12-23 months in Dschang, West Region, Cameroon: a cross-sectional survey during a polio outbreak. BMC public health, 15(1), 1-11.

The National Expanded Programme on Immunization (2020). South Sudan national expanded programme on immunization Multi-Year Plan 2018 - 2022. Ministry of Health: Government of South Sudan

The National Expanded Programme on Immunization. (2017). South Sudan national expanded programme on immunization Multi-Year Plan 20011 - 20116. Ministry of Health: Government of South Sudan.

The National Expanded Programme on Immunization. (2018). South Sudan national expanded programme on immunization Multi-Year Plan 2018 - 2022. Ministry of Health: Government of South Sudan

Wado, Y. D., Afework, M. F., \& Hindin, M. J. (2014). Childhood vaccination in rural southwestern Ethiopia: the nexus with demographic factors and women's autonomy. The Pan African Medical Journal, 17(Suppl 1). https://doi.org/10.11604/pamj.supp.2014.17.1.3135

Wallace, A. S., Krey, K., Hustedt, J., Burnett, E., Choun, N., Daniels, D., ... \& Duncan, R. (2018). Assessment of vaccine wastage rates, missed opportunities, and related knowledge, attitudes and practices during introduction of a second dose of measles- containing vaccine into Cambodia's national immunization program. Vaccine, 36(30), 4517-4524.32. https://doi.org/10.1016/j.vaccine.2018.06.009

World Health Organization. (2012). Global routine vaccination coverage, 2011. Weekly Epidemiological Record= Relevé épidémiologique hebdomadaire, 87(44), 432-435.

World Health Organization. (2013). Global routine vaccination coverage, 2012. Weekly Epidemiological Record= Relevé épidémiologique hebdomadaire, 88(44-45), 482-486.

World Health Organization. (2014). Global routine vaccination coverage, 20131. Weekly Epidemiological Record $=$ Relevé épidémiologique hebdomadaire, 89(47), 517-522.

World Health Organization. (2016). State of inequality: childhood immunization. 13.

World Health Organization. (2017). A guide for conducting an Expanded Programme on Immunization (EPI) review (No. WHO/IVB/17.17). World Health Organization.

World Health Organization. (2018). 2018 assessment report of the Global Vaccine Action Plan: strategic advisory group of experts on immunization (No. WHO/IVB/18.11). World Health Organization. 
World Health Organization. (2018). World Health Organization vaccination coverage cluster surveys: reference manual (No. WHO/IVB/18.09). World Health Organization.

World Health Organization. (2019). Global Health Observatory (GHO) data. Geneva.

Zewdie, A., Letebo, M., \& Mekonnen, T. (2016). Reasons for defaulting from childhood immunization program: a qualitative study from Hadiya zone, Southern Ethiopia. BMC public health, 16(1), 1-9. https://doi.org/10.1186/s12889-016-3904-1

\section{Copyrights}

Copyright for this article is retained by the author(s), with first publication rights granted to the journal.

This is an open-access article distributed under the terms and conditions of the Creative Commons Attribution license (http://creativecommons.org/licenses/by/4.0/). 